\title{
Detection and characterization of nitric oxide synthase in the mammalian cochlea
}

\author{
James D. Fessenden ${ }^{\mathrm{a}, \mathrm{b}}$, Donald E. Coling ${ }^{\mathrm{a}}$, Jochen Schacht ${ }^{\mathrm{a}, \mathrm{b}, *}$ \\ ${ }^{a}$ Kresge Hearing Research Institute, Department of Otolaryngology, University of Michigan, Ann Arbor, MI 48109-0506, USA \\ ${ }^{\mathrm{b}}$ Department of Biological Chemistry, University of Michigan, Ann Arbor, MI 48109, USA
}

Accepted 20 September 1994

\begin{abstract}
The messenger molecule nitric oxide (NO) is involved in blood flow regulation, cytotoxicity, and neural signalling, processes that are important in the physiology and pathophysiology of the mammalian cochlea. However, neither the presence of NO nor its synthetic enzyme, NO synthase, has been established in the peripheral auditory system. NO synthase activity, measured as the enzymatic conversion of radioactive arginine to citrulline, was predominantly soluble in the auditory nerve, lateral wall, vestibule and cochlear neuroepithelium. $N$-methyl-L-arginine and trifluoperazine inhibited NO synthase activity in the lateral wall and auditory nerve. Histochemical staining by NADPH-diaphorase localized NOS activity to the lateral wall and the neuronal elements of the organ of Corti. Based on these results, the predominant NO synthase isoform in the cochlea is the neuronal type-I isoform.
\end{abstract}

Keywords: Nitric oxide; Cochlea; NADPH-diaphorase; Outer hair cell; NMMA

\section{Introduction}

The chemical messenger nitric oxide (NO) has been implicated in a wide variety of biological phenomena including neurotransmission, cytotoxicity, and blood flow regulation. NO is a gas and thus can cross membranes readily and affect neighboring cells. It exerts many of its effects by activating the soluble isoform of guanylate cyclase [5], an enzyme which converts GTP to cGMP. The cGMP, in turn, affects cellular physiology through the activation of cGMP-dependent protein kinases [27]. Proteins whose activities are modulated by this kinase include a plasma-membrane $\mathrm{Ca}^{2+}$-ATPase and $\mathrm{a} \mathrm{Na}{ }^{+} / \mathrm{Ca}^{2+}$ exchanger [14,33]. NO also affects cellular physiology independent of the cGMP system. NO stimulates the ADP-ribosylation of enzymes such as glyceraldehyde-3-phosphate dehydrogenase [21], thus resulting in a modulation of activity. In addition, NO

\footnotetext{
* Corresponding author. Kresge Hearing Research Institute, University of Michigan, 1301 East Ann Street, Ann Arbor, MI 481090506, USA. Fax: (1) (313) 764-0014.
}

can directly inhibit enzymes involved in the mitochondrial electron transport chain [15]. Finally, as a free radical, NO participates in radical-mediated cell death by reacting with superoxide to produce the highly cytotoxic compound, peroxynitrite [2].

NO is synthesized by the enzyme nitric oxide synthase (NOS) which catalyzes the oxidation of the terminal guanidinium nitrogen in the amino acid L-arginine to form NO and L-citrulline [20]. Three distinct isoforms of this enzyme have been characterized which vary in $\mathrm{Ca}^{2+} /$ calmodulin dependency, subcellular localization, mode of induction, and tissue expression. Type-I NOS activity is $\mathrm{Ca}^{2+} /$ calmodulin-dependent, cytosolic and constitutively expressed [7]. First localized in brain, this isozyme has since been found in many locations including the pancreas [28], corpus cavernosum [8], and neurons innervating the gastrointestinal lining of the gut [34]. In these tissues, NO participates in insulin secretion, penile erection, and peristalsis, respectively. In the brain, NO synthesized by this isozyme may act as a neuromodulator in glutamate neurotransmission [5]. Moreover, a role for NO in long-term potentiation has been proposed [23]. In contrast to the neuronal type-I NOS, type-II NOS is not 
constitutively expressed but can be induced in many tissues such as smooth muscle, macrophages, glia, and liver [22]. In macrophages, type-II NOS is induced in response to a bacterial infection, and the NO produced can kill the invading cells. However, the function of type-II NOS in other cell types is unknown. Type-III NOS is distinctly localized to the endothelial lining of blood vessels where NO acts as a vasodilator [24] via relaxation of the smooth muscle surrounding the vessel. Similar to type-I NOS, this isozyme is constitutively expressed and $\mathrm{Ca}^{2+} /$ calmodulin dependent $[18,25]$. However, type-III NOS is unique among the three isoforms in that it is localized to the plasma membrane due to posttranslational $N$-myristoylation [29]. The vasodilatory action of several hormones including bradykinin and acetylcholine is thought to be mediated by type-III NOS in the endothelium [16].

The three best studied effects of NO, modulation of neurotransmission, regulation of blood flow, and induction of cytotoxicity are all involved in the physiology or pathophysiology of the mammalian cochlea. In fact, several key components of the NO/cGMP signal transduction pathway have already been demonstrated in the sensory tissues of the inner ear. Calmodulin [30], cGMP [32], and a potential cGMP-dependent protein kinase substrate [9] are present in the neuroepithelium. Although NOS localization has been attempted in central auditory structures [12] little information concerning the presence or distribution of NOS in the cochlea is known. We assessed the biochemical activity of NOS in the lateral wall, auditory nerve, cochlear neuroepithelium, and vestibule. Using a combination of histochemical and enzymatic methods, we characterized NOS in these tissues and determined the location and nature of the NOS isoforms present in the peripheral auditory system.

\section{Materials and Methods}

Except where noted, all chemicals were purchased from Sigma chemical company (St. Louis, MO).

NOS was localized in cochlear tissues using NADPH-diaphorase histochemistry. Adult pigmented guinea pigs (Murphy Laboratories, Plainfield, IN) were decapitated and the bullae removed, opened, and placed in $1 \%$ paraformaldehyde in phosphate buffered saline (PBS). PBS consisted of $80 \mathrm{mM} \mathrm{Na}{ }_{2} \mathrm{HPO}_{4}, 100 \mathrm{mM} \mathrm{NaCl}$ with the $\mathrm{pH}$ adjusted to 7.5 using $\mathrm{HCl}$. The cochleae were perfused with $1 \%$ paraformaldehyde/PBS through the round window and maintained in this solution for $3 \mathrm{~h}$ at $4^{\circ} \mathrm{C}$. They were then rinsed 3 times in PBS, and the lateral wall was removed and stained as described below. The modiolus containing the sensory epithelium was then removed from the temporal bone and placed in NADPH-diaphorase staining solution consisting of $0.2 \%$ Triton $X-100,1 \mathrm{mM}$ nitro blue tetrazolium (NBT), $1 \mathrm{mM}$ NADP, $15 \mathrm{mM}$ malic acid, $1 \mathrm{mM} \mathrm{MnCl}_{2}$ (Mallinckrodt, St. Louis, MO), $50 \mathrm{mM}$ Tris base with the pH adjusted to 8.0 using $\mathrm{HCl}$. After $1 \mathrm{~h}$, the reaction was stopped by placing the modiolus in $10 \mathrm{ml}$ of PBS and dissecting the neuroepithelium. The dissected tissue was mounted onto slides using $50 \%$ glycerol (Merck, Rahway, NJ). The tissue was visualized under brightfield microscopy.

The NADPH-diaphorase reaction was also performed on cells isolated from neuroepithelium. The sensory epithelium was dissected from freshly isolated cochleae in Hanks' Balanced Salt Solution (Gibco-BRL, Gaithersburg, MD) consisting of $137 \mathrm{mM} \mathrm{NaCl}, 5.4$ $\mathrm{mM} \mathrm{KCl}, 1.25 \mathrm{mM} \mathrm{CaCl}_{2}, 0.5 \mathrm{mM} \mathrm{MgCl}, 0.4 \mathrm{mM} \mathrm{MgSO}, 0.33 \mathrm{mM}$ $\mathrm{Na}_{2} \mathrm{HPO}_{4}, 0.44 \mathrm{mM} \mathrm{KH} \mathrm{PO}_{4}, 5.5 \mathrm{mM}$ D-glucose, $5 \mathrm{mM} N$-[2-hydroxyethyl]piperazine- $\mathrm{N}^{\prime}$-[2-ethanesulfonic acid] (HEPES) buffered to $\mathrm{pH} 7.4$ with $\mathrm{NaOH}$ and adjusted to $300 \pm 2 \mathrm{mOsM}$ using $4 \mathrm{M}$ $\mathrm{NaCl}$. Tissue sections containing Hensen's cells, outer hair cells and Deiters' cells were obtained by microdissection and incubated for 15 min in type IV collagenase diluted to $0.5 \mathrm{mg} / \mathrm{ml}$ in Hanks' medium. Cells were then dispersed into a fresh droplet of Hanks' medium. The dissociated cells were maintained in $1 \%$ paraformaldehyde/PBS for $2 \mathrm{~h}$ at $4^{\circ} \mathrm{C}$. The cells were pelleted at $1000 \times g$ for $10 \mathrm{~min}$ and placed onto coverslips coated with $0.1 \%$ polyethylenimine. They were washed several times with Hanks' medium and then incubated with the NADPH-diaphorase staining solution for $1 \mathrm{~h}$ at $37^{\circ} \mathrm{C}$.

Tissue was prepared for NOS enzymatic assays using the following procedure. Pigmented guinea pigs were decapitated and the bullae quickly removed and placed in Hanks' medium. The auditory nerve, neuroepithelium, lateral wall, and vestibular tissues were dissected and homogenized in buffer containing $50 \mathrm{mM}$ HEPES, 3 $\mathrm{mM}$ ethylenediaminetetraacetic acid (EDTA), $3 \mathrm{mM}$ ethylene glycolbis ( $\beta$-aminoethyl ether) $N, N, N^{\prime}, N^{\prime}$-tetraacetic acid (EGTA) and the $\mathrm{pH}$ adjusted to 7.4. The neuroepithelium was homogenized in $25 \mu \mathrm{l}$ of this buffer whereas the other tissues were homogenized in $50 \mu \mathrm{l}$. The tissues were homogenized twice on ice using $200 \mu \mathrm{l}$ glass microhomogenizers (Kontes Life Sciences, Vineland, NJ) and then centrifuged at $10,000 \times g$ for 15 min to pellet cell membranes. In some experiments, the pelleted fraction was resuspended in an equal volume of homogenization buffer and also used for NOS activity determinations. The supernatant fraction was removed and centrifuged at $100,000 \times g$ for $1 \mathrm{~h}$. The $100,000 \times g$ supernatant was used for the NOS assays.

NOS activity in inner ear tissues was assessed using a modified procedure of published methods [19]. L- $\left[2,3-{ }^{3} \mathrm{H}\right]$ arginine from New England Nuclear $(36.1 \mathrm{Ci} / \mathrm{mmol})$ was purified before each experiment by anion exchange chromatography. Dowex-1 resin ( $\mathrm{Cl}^{-}$form) was added to warm $\left(\sim 70^{\circ} \mathrm{C}\right) 1 \mathrm{M} \mathrm{NaOH}$ and allowed to settle. $\mathrm{A} 0.5$ $\mathrm{ml}$ column was poured and washed with $\mathrm{H}_{2} \mathrm{O}\left(\sim 70^{\circ} \mathrm{C}\right)$ until the $\mathrm{pH}$ was neutral. $\left[{ }^{3} \mathrm{H}\right]$ arginine was added to the column and the first peak of radioactivity was collected. This peak contained the purified $\left[{ }^{3} \mathrm{H}\right.$ ]arginine. Assays were conducted in a $30 \mu \mathrm{l}$ volume in $16 \mathrm{mM}$ HEPES, $3 \mu \mathrm{M}$ calmodulin, $3 \mathrm{mM} \mathrm{CaCl}, 1 \mathrm{mM}$ EDTA, $1 \mathrm{mM}$ EGTA and $100 \mu \mathrm{M}$ NADPH, pH 7.4. The initial $\left[{ }^{3} \mathrm{H}\right]$ arginine level was $250,000 \mathrm{dpm}$ in all experiments except in the experiments shown in Fig. 3 where $400,000 \mathrm{dpm}$ were added. Assays were run at room temperature for $15 \mathrm{~min}$ except in the experiments shown in Fig. 3 where the reaction time was extended to $60 \mathrm{~min}$. Reactions were terminated by the addition of $0.5 \mathrm{ml}$ of buffer containing $50 \mathrm{mM}$ HEPES, $2 \mathrm{mM}$ EDTA with the $\mathrm{pH}$ adjusted to 5.5 using $\mathrm{HCl}$. The entire reaction mix was loaded onto a 1 ml AG50WX-8 column $\left(\mathrm{Na}^{+}\right.$ form, BioRad, Richmond, CA) and the column was washed with 0.5 $\mathrm{ml}$ of the buffer used to terminate the reaction. The column retained $\left[{ }^{3} \mathrm{H}\right]$ arginine and excluded $\left[{ }^{3} \mathrm{H}\right]$ citrulline as confirmed by thin layer chromatographic analysis (see below).

Enzyme activities were determined by subtracting the dpm in the citrulline fraction of a control reaction (-NADPH) from the experimental value. NOS specific activity was expressed as dpm of $\left[{ }^{3} \mathrm{H}\right.$ )citrulline formed $\mathrm{min}^{-1} \mathrm{mg}$ protein ${ }^{-1}$. Protein concentrations were determined using the BioRad protein assay kit (BioRad, Richmond, CA) and bovine serum albumin as standard.

Arginine to citrulline conversion was also determined using thin layer chromatography (TLC). Auditory nerve tissue from 6 cochleae was homogenized as described above and the $10,000 \times g$ supernatant 
was used. The reaction volume was increased to $100 \mu \mathrm{l}$. At $10 \mathrm{~min}$ intervals, $10 \mu \mathrm{l}$ aliquots of the reaction mix were spotted onto a $20 \times 20 \mathrm{~cm}$ silica gel G TLC plate (Uniplate cat\# 80013, Newark, DE). Unlabeled L-arginine and L-citrulline (26 and $18 \mu \mathrm{g}$ respectively) were added as carriers. The spots were dried and the plate was developed in 5:30:2:5 $n$-butanol:acetone:diethylamine:water. The plates were sprayed with $0.1 \mathrm{mg} / \mathrm{ml}$ fluorescamine in acetone to visualize the arginine and citrulline bands. These bands were scraped and the amount of $\left[{ }^{3} \mathrm{H}\right]$ arginine and $\left[{ }^{3} \mathrm{H}\right]$ citrulline was determined by scintillation counting.

\section{Results}

We first characterized NOS activity in the soluble fraction of the auditory nerve. $\left[{ }^{3} \mathrm{H}\right]$ citrulline was produced by the auditory nerve in a linear time-dependent fashion in the presence but not in the absence of the NOS cosubstrate NADPH (Fig. 1). The production of citrulline could be abolished by first heating the enzyme fractions at $100^{\circ} \mathrm{C}$ for $15 \mathrm{~min}$ (Fig. 1 inset).

Enzyme-specific inhibitors confirmed that the observed conversion of arginine to citrulline was catalyzed by NOS. $N^{G}$-methyl-L-arginine (NMMA) and the calmodulin antagonist trifluoperazine (TFP) are effective inhibitors of the neuronal type-I isoform [6]. Both of these compounds significantly reduced arginine to citrulline conversion catalyzed by cochlear tissues. In lateral wall, the soluble NOS activity of 2610

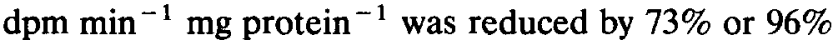
in the presence of $50 \mu \mathrm{M}$ TFP or NMMA, respectively.

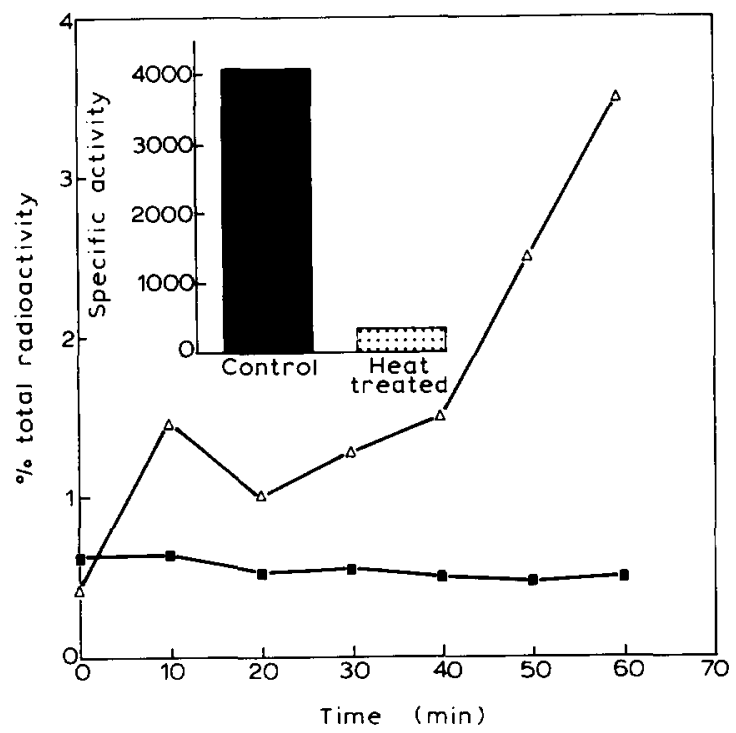

Fig. 1. NOS activity in auditory nerve. $\left[{ }^{3} \mathrm{H}\right]$ citrulline was separated from $\left[{ }^{3} \mathrm{H}\right]$ arginine by $\mathrm{TLC}$ as described in Methods. Arginine to citrulline conversion was observed in the presence of $10 \mathrm{mM} \mathrm{NADPH}$ (triangles) but not in its absence (squares). [ $\left.{ }^{3} \mathrm{H}\right]$ citrulline produced is expressed as the percentage of total radioactivity recovered from each time point. Inset: NADPH-dependent citrulline production is abolished by prior incubation of the tissue at $100^{\circ} \mathrm{C}$ for $15 \mathrm{~min}$. Specific activity is defined in Methods.

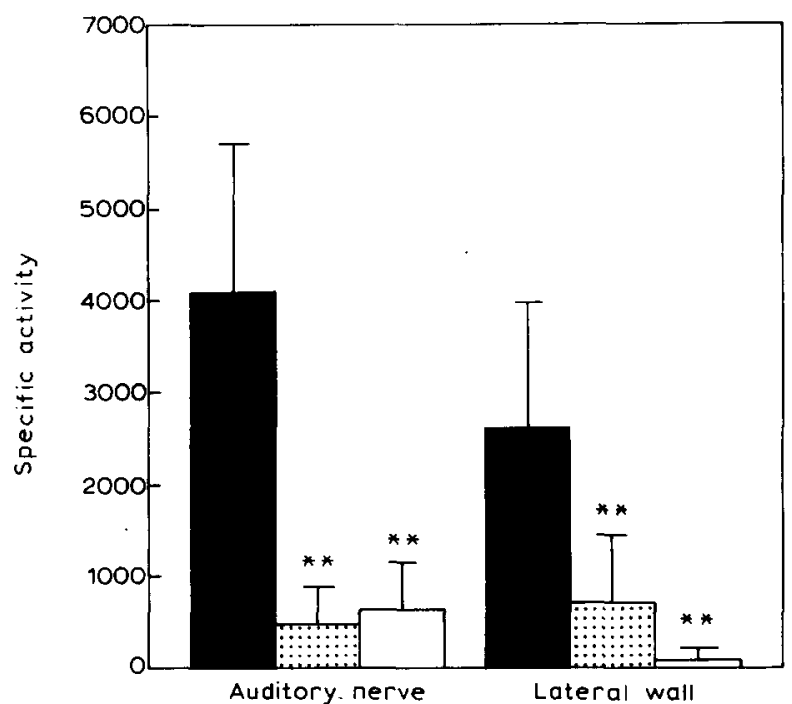

Fig. 2. NOS inhibitors block cochlear NOS activity. NOS activity was assayed as described in Methods. Cytosolic NOS activity (black bars) was inhibited by either $50 \mu \mathrm{M}$ TFP (stippled bars) or $50 \mu \mathrm{M}$ NMMA (unfilled bars) in auditory nerve and lateral wall. When TFP was tested, calmodulin was not added to the assay. Each point is the mean \pm S.D. of either 17 experiments (controls) or 3-8 experiments (inhibitors). Data are expressed as dpm citrulline produced min $^{-1}$ $\mathrm{mg}$ protein ${ }^{-1}$. Statistical significance of differences between experiments in the absence and presence of inhibitors was determined by Student's $t$-test $\left({ }^{* *} P<0.001\right)$.

In auditory nerve, soluble actvitiy of $4090 \mathrm{dpm} \min ^{-1}$ mg protein ${ }^{-1}$ was reduced by $88 \%$ or $84 \%$ in the presence of $50 \mu \mathrm{M}$ TFP or NMMA respectively (Fig. 2).

NOS was present in roughly equal specific activities in the lateral wall, auditory nerve, cochlear neuroepithelium, and pooled utricule and crista ampullaris tissues (Fig. 3). These activities ranged from 1343 to $3092 \mathrm{dpm} \min ^{-1} \mathrm{mg}$ protein ${ }^{-1}$. Also, the majority of the NOS activity was cytosolic indicating that the soluble NOS isoforms (type-I and type-II) predominate in the inner ear. Consistent with the finding in cochlear tissues, NOS activity in the vestibular tissues also could be completely inhibited by NMMA in 2 independent experiments (data not shown).

NADPH-diaphorase histochemistry was performed to identify the cell types containing NOS in the cochlea. In brain, cells stained by this technique colocalize with cells recognized by NOS immunohistochemistry [10]. NADPH-diaphorase histochemical staining in the cochear neuroepithelium labeled the nerve endings at the base of inner and outer hair cells, tunnel crossing fibers, tunnel and inner spiral bundles, and nerve fibers entering through the habenula perforata (Fig. 4a,b). The finding that NADPH-diaphorase activity was located at the base of outer hair cells was confirmed by experiments on isolated cells (Fig. 4c). In control experiments conducted in the absence of NADP, no 


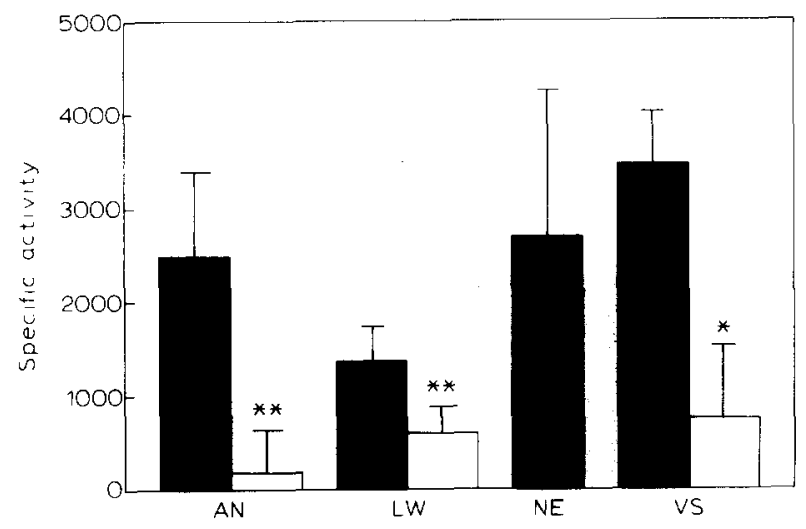

Fig. 3. NOS activity in cochlear tissues. Cytosolic (solid) and particulate (clear) NOS activity is found in auditory nerve (AN), lateral wall (LW), cochlear neuroepithelium (NE), and pooled utricle and cristae ampullaris (VS). No particulate NOS activity could be measured in the cochlear neuroepithelium. Assays were conducted in the presence of $400,000 \mathrm{dpm}$ of $\left[{ }^{3} \mathrm{H}\right] \mathrm{arginine}$ for $60 \mathrm{~min}$. Each point is the mean \pm S.D. of 6 independent experiments except for the vestibular tissues which were assayed 3 times. Statistical significance of differences between particulate and cytosolic activities were assessed using Student's $t$-test $\left({ }^{*} 0.02<P<0.01,{ }^{* *} P<0.001\right)$.

staining was observed in the neuroepithelium (Fig. 4d) or the lateral wall (Fig. 4f). In the lateral wall tissues, the NADPH-diaphorase reaction stained the stria vascularis and the region of the spiral prominence (Fig. $4 \mathrm{e})$. No labeling of the spiral ligament was observed in cross-sections of stained lateral wall tissue (data not shown).

\section{Discussion}

NOS is present in the peripheral auditory system. NOS activity can be quantitated enzymatically in the auditory nerve, cochlear neuroepithelium, lateral wall, and vestibule. NADPH-diaphorase activity, which has been used to localize NOS in neural tissues [10] shows a distinct staining pattern in both the lateral wall and neuroepithelium.

In the auditory nerve, NOS activity is predominantly cytosolic and can be inhibited by both NMMA and TFP, unique characteristics of the neuronal type-I isoform [27]. This finding is in agreement with the neuronal nature of this tissue. In neurons, NO produced from type-I NOS can act as a neuromodulator or even as a neurotransmitter [5]. It is possible that NO pro- duced from type-I NOS may be playing a similar role in the auditory nerve.

Similar to auditory nerve, NOS activity in the lateral wall is predominantly cytosolic and $\mathrm{Ca}^{2+} /$ calmodulindependent thus indicating type-I NOS activity. NOS can also be localized histochemically by NADPH-diaphorase labeling. Type-III NOS could not be detected in our experiments as indicated by the lack of particulate activity. The absence of type-III NOS activity is unexpected since this isozyme is generally associated with blood vessels and thus may be expected in the highly vascularized lateral wall tissue. Type-III NOS activity in the lateral wall may have been below the detection threshold of our assay, a distinct possibility since type-III NOS has the lowest catalytic rate of the three NOS isoforms [31]. Although NO can affect cochlear blood flow [4], the lack of type-III NOS as well as smooth muscle lining strial vessels indicates that NO blood flow regulation may occur at some other location or through some novel mechanism in the lateral wall.

In the cochlear neuroepithelium, the NADPH-diaphorase reaction labels the neural elements innervating both inner and outer hair cells. However, in some experiments, additional cell types such as interdental cells of the spiral limbus, pillar, and Deiters' cells were stained. It should be noted that the correlation between cells recognized by the NADPH-diaphorase technique and immunocytochemistry using anti-NOS-I antibodies is the strongest in neurons [10]. In non-neuronal cells in the peripheral olfactory tissues, NADPH-diaphorase staining results in labeling of nonNOS-I immunoreactive cells [17]. Thus, NADPH-diaphorase labeling of cochlear supporting cells may not indicate the presence of NOS. In contrast, the combination of NADPH diaphorase staining in the neuronal elements of the cochlear neuroepithelium and enzymatic detection of NOS activity in this tissue strongly suggests that NOS is located in the neurons.

In cochlear surface preparations, dense punctate staining is observed at the base of both inner and outer hair cells. Studies on isolated outer hair cells confirm the presence of labeling at the base of the cell and also demonstrate the lack of stain in the cytoplasm. The labeling at the base of the outer hair cells is connected to the tunnel crossing fibers which also are identified by NADPH-diaphorase histochemistry. The staining pattern of the tunnel crossing fibers is very similar to

Fig. 4. Localization of NOS in cochlear tissues using NADPH-diaphorase histochemistry. Cochlear neuroepithelium and lateral wall tissues were stained as described in Methods. A: in the cochlear neuroepithelium, nerve endings at the base of outer (arrow) and inner hair cells (arrowhead) are stained. B: the same area as in A at a different focal plane shows labeling in tunnel crossing fibers (CF), the inner spiral bundle (ISB), the tunnel spiral bundle (TSB) and fibers entering through the habenula perforata (arrow). C: nerve endings of isolated outer hair cells are stained (arrow). D: control. No staining is observed in the neuroepithelium in the absence of NADP. E: in the lateral wall, the region of the stria vascularis (SV) and the spiral prominence (SP) is labeled. F: control labeling experiments as in D do not label the lateral wall. Scale bar $=10 \mu \mathrm{m}$. 

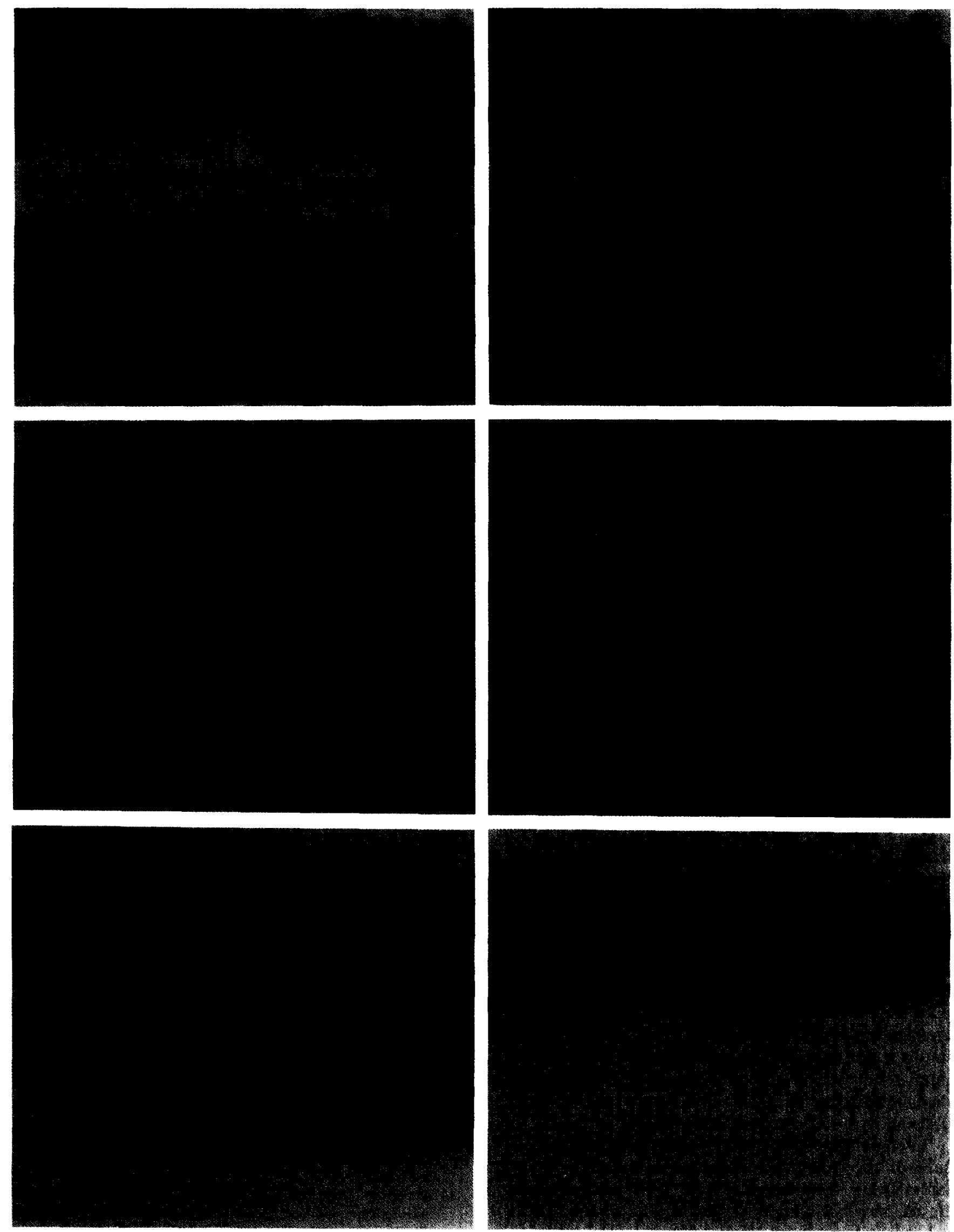
the pattern observed using anti-choline:acetyltransferase immunocytochemistry which selectively stains efferent neurons in the organ of Corti [1]. Thus it is likely that NOS is located in efferent neurons innervating the outer hair cells. Punctate NADPH-diaphorase staining near inner hair cells is also observed and spiral ganglion cells can be labeled (data not shown) in agreement with a previous report [35]. Thus, NOS may also be located in type-I afferent neurons. In contrast, no NADPH-diaphorase labeling occurs in the cytoplasm of inner or outer hair cells.

Most documented NO-mediated processes involve paracrine signalling whereby NO produced from one cell type diffuses to a neighboring cell type and affects its physiology. In the cochlea, a similar situation may exist whereby NO produced from nerve endings could diffuse to the hair cells and affect their physiology directly.

In this fashion, NO could conceivably affect many hair cell processes. NO can lower the cytosolic free $\left[\mathrm{Ca}^{2+}\right]$ in smooth muscle which leads to a change in cell shape [3]. By analogy, NO produced from efferent nerve endings could lower the cytosolic $\left[\mathrm{Ca}^{2+}\right]$ in outer hair cells and affect their length which is $\mathrm{Ca}^{2+}$-dependent [13]. Thus, outer hair cell length and the micromechanics of the basilar membrane could be modulated by NO-mediated efferent stimulation. Regulation of the cytosolic $\left[\mathrm{Ca}^{2+}\right]$ could also affect other inner and outer hair cell processes such as neurotransmitter release. Release of neurotransmitters is dependent on an increase in intracellular $\left[\mathrm{Ca}^{2+}\right]$. By lowering calcium levels in hair cells, NO could downregulate the release of neurotransmitter and affect cochlear sound transduction.

NO is also a cytotoxin. Overstimulation of NOS-containing neurons by glutamate agonists leads to overproduction of NO and the death of surrounding neurons [11]. In the cochlea, excessive acoustic stimulation damages the afferent neurons innervating the inner hair cell. Perfusion of the glutamate receptor agonist AMPA into the cochlea mimics the excitotoxic damage [26] suggesting that overstimulaton of glutamate receptors is associated with this damage. Overstimulation of NOS located in the afferent nerve endings either through acoustic or glutamate stimulation could produce excessive amounts of NO which could in turn damage the surrounding tissue. The presence of NOS in this region supports this hypothesis. Pharmacological intervention with NOS inhibitors should reduce this damage and thus may have some clinical benefits in the prevention of noise-induced hearing loss.

In summary, NOS activity is present in several tissues of the inner ear including the auditory nerve, lateral wall, vestibule and cochlear neuroepithelium. Based on subcellular fractionation and pharmacological characterization of this activity, the prominent iso- form in the cochlea is the neuronal type-I isozyme. NOS is localized to the stria vascularis as well as neurons synapsing on the inner and outer hair cells. Due to the wide range of effects attributed to NO in other systems, it is likely that NO is an important signalling molecule in the auditory system as well.

\section{Acknowledgements}

The authors would like to thank Drs. Richard Altschuler and Joseph Hawkins for their helpful advice on cochlear anatomy. This research was supported by grants from the Deafness Research Foundation and the National Institutes of Health (DC-00078).

\section{References}

[1] Altschuler, R.A., Kachar, B., Rubio, J.A., Parakkal, M.A. and Fex, J., Immunocytochemical localization of choline acetyltransferase-like immunoreactivity in the guinea pig cochlea, Brain Res., 338 (1985) 1-11.

[2] Beckman, J.S., Beckman, T.W., Chen, J., Marshall, P.A. and Freeman, B.A., Apparent hydroxyl radical production by peroxynitrite: implications for endothelial injury from nitric oxide and superoxide, Proc. Natl. Acad. Sci. USA, 87 (1990) 1620-1624.

[3] Blatter, L.A. and Wier, W.G., Nitric oxide decreases $\left[\mathrm{Ca}^{2+}\right] \mathrm{i}$ in vascular smooth muscle by inhibition of the calcium current, Cell Calcium, 15 (1994) 122-131.

[4] Brechtelsbauer, P.B., Nuttall, A.L. and Miller, J.M., Basal nitric oxide production in regulation of cochlear blood flow, Hear. Res., 77 (1994) 38-42.

[5] Bredt, D.S. and Snyder, S.H., Nitric oxide mediates glutamatelinked enhancement of cGMP levels in the cerebellum, Proc. Natl. Acad. Sci. USA, 86 (1989) 9030-9033.

[6] Bredt, D.S. and Snyder, S.H., Isolation of nitric oxide synthase, a calmodulin-requiring enzyme, Proc. Natl. Acad. Sci. USA, 87 (1990) 682-685.

[7] Bredt, D.S., Hwang, P.M., Glatt, C.E., Lowenstein, C., Reed, R.R. and Snyder, S.H., Cloned and expressed nitric oxide synthase structurally resembles cytochrome $\mathrm{P}-450$ reductase, $\mathrm{Na}$ ture, 351 (1991) 714-718.

[8] Burnett, A.L., Lowenstein, C.J., Bredt, D.S., Chang, T.S. and Snyder, S.H., Nitric oxide: a physiologic mediator of penile erection, Science, 257 (1992) 401-403.

[9] Coling, D.E. and Schacht, J., Protein phosphorylation in the organ of Corti: differential regulation by second messengers between base and apex, Hear. Res., 57 (1991) 113-120.

[10] Dawson, T.M., Bredt, D.S., Fotuhi, M., Hwang, P.M. and Snyder, S.H., Nitric oxide synthase and neuronal NADPH diaphorase are identical in brain and peripheral tissues, Proc. Natl. Acad. Sci. USA, 88 (1991) 7797-7801.

[11] Dawson, V.L., Dawson, T.M., Bartley, D.A., Uhl, G.R. and Snyder, S.H., Mechanisms of nitric oxide-mediated neurotoxicity in primary brain cultures, $J$. Neurosci., 13 (1993) 2651-2661.

[12] Druga, R. and Syka, J., NADPH-diaphorase activity in the central auditory structures of the rat, Neuroreport, 4 (1993) 999-1002.

[13] Dulon, D., Zajic, G. and Schacht, J., Increasing intracellular free calcium induces circumferential contractions in isolated cochlear outer hair cells, $J$. Neurosci., 10 (1990) 1388-1397. 
[14] Furukawa, K., Ohshima, N., Tawada-Iwata, Y. and Shigekawa, M., Cyclic GMP stimulates $\mathrm{Na}^{+} / \mathrm{Ca}^{2+}$ exchange in vascular smooth muscle cells in primary culture, J. Biol. Chem., 266 (1991) 12337-12341.

[15] Geng, Y., Hansson, G.K. and Holme, E., Interferon-gamma and tumor necrosis factor synergize to induce nitric oxide production and inhibit mitochondrial respiration in vascular smooth muscle cells, Circ. Res., 71 (1992) 1268-1276.

[16] Ignarro, L.J., Byrns, R.E., Buga, G.M. and Wood, K.S., Endothelium-derived relaxing factor from pulmonary artery and vein possesses pharmacologic and chemical properties identical to those of nitric oxide radical, Circ. Res., 61 (1987) 866-879.

[17] Kishimoto, J., Keverne, E.B., Hardwick, J. and Emson, P.C., Localization of nitric oxide synthase in the mouse olfactory and vomeronasal system: a histochemical, immunological and in situ hybridization study, Eur. J. Neurosci., 5 (1993) 1684-1694.

[18] Knowles, R.G. and Moncada, S., Nitric oxide as a signal in blood vessels, Trends Biochem. Sci., 17 (1992) 399-402.

[19] Knowles, R.G., Palacios, M., Palmer, R.M.J. and Snyder, S.H., Formation of nitric oxide from L-arginine in the central nervous system: a transduction mechanism for stimulation of the soluble guanylate cyclase, Proc. Natl. Acad. Sci. USA, 86 (1989) 51595162.

[20] Marletta, M.A., Nitric oxide synthase structure and mechanism, J. Biol. Chem., 268 (1993) 12231-12234.

[21] Molina y Vedia, L., McDonald, B., Reep, B., Brüne, B., Di Silvio, M., Billiar, T.R. and Lapetina, E.G., Nitric oxide-induced $S$-nitrosylation of glyceraldehyde-3-phosphate dehydrogenase inhibits enzymatic activity and increases endogenous ADPribosylation, J. Biol. Chem., 267 (1992) 24929-24932.

[22] Nussler, A.K. and Billiar, T.R., Inflammation, immunoregulation, and inducible nitric oxide synthase, J. Leuk. Biol., 54 (1993) 171-178.

[23] O'Dell, T.J., Hawkins, R.D., Kandel, E.R. and Arancio, O., Tests of the roles of two diffusible substances in long-term potentiation: evidence for nitric oxide as a possible early retrograde messenger, Proc. Natl. Acad. Sci. USA, 88 (1991) 1128511289.

[24] Palmer, R.M.J., Ferrige, A.G. and Moncada, S., Nitric oxide release accounts for the biological activity of endothelium-derived relaxing factor, Nature, 327 (1987) 524-5296.

[25] Pollock, J.S., Förstermann, U., Mitchell, J.A., Warner, T.D., Schmidt, H.H.H.W., Nakane, M. and Murad, F., Purification and characterization of particulate endothelium-derived relaxing factor synthase from cultured and native bovine aortic endothelial cells, Proc. Natl. Acad. Sci. USA 88 (1991) 1048010484.

[26] Puel, J.-L., Pujol, R., Ladrech, S. and Eybalin, M., $\alpha$-Amino-3hydroxy-5-methyl-4-isoxazole propionic acid electrophysiological and neurotoxic effects in the guinea-pig cochlea, Neuroscience, 45 (1991) 63-72.

[27] Schmidt, H.H.H.W., Lohmann, S.M. and Walter, U., The nitric oxide and cGMP signal transduction system: regulation and mechanism of action, Biochim. Biophys. Acta, 1178 (1993) 153175.

[28] Schmidt, H.H.H.W., Warner, T.D., Ishii, K., Sheng, H. and Murad, F., Insulin secretion from pancreatic B cells caused by L-arginine-derived nitrogen oxides, Science, 255 (1992) 721-723.

[29] Sessa, W.C., Barber, C.M. and Lynch, K.R., Mutation of $N$ myristoylation site converts endothelial cell nitric oxide synthase from a membrane to a cytosolic protein, Circ. Res., 72 (1993) 921-924.

[30] Slepecky, N., Ulfendahl, M. and Flock, A., Effects of caffeine and tetracaine on outer hair cell shortening suggest intracellular calcium involvement, Hear. Res., 32 (1988) 11-22.

[31] Tracey, W.R., Nakane, M., Pollock, J.S. and Förstermann, U., Nitric oxide synthases in neuronal cells, macrophages and endothelium are NADPH diaphorases, but represent only a fraction of total cellular NADPH diaphorase activity, Biochem. Biophys. Res. Commun., 195 (1993) 1035-1040.

[32] Thalmann, R., Paloheimo, S. and Thalmann, I., Distribution of cyclic nucleotides in the organ of Corti, Acta Otolaryngol., 87 (1979) 375-380.

[33] Yoshida, Y., Sun, H., Cai, J. and Imai, S., Cyclic GMP-dependent protein kinase stimulates the plasma membrane $\mathrm{Ca}^{2+}$ pump ATPase of vascular smooth muscle via phosphorylation of a 240-kDa protein, J. Biol. Chem., 266 (1991) 19819-19825.

[34] Young, H.M., Furness, J.B., Shuttleworth, C.W., Bredt, D.S. and Snyder, S.H., Co-localization of nitric oxide synthase immunoreactivity and NADPH diaphorase staining in neurons of the guinea-pig intestine, Histochemistry, 97 (1992) 375-378.

[35] Zdanski, C.J., Prazma, J., Petrusz, P., Grossman, G., Raynor, E and Pillsbury, H.C., Nitric oxide synthase is an active enzyme in the spiral ganglion cells of the rat cochlea, Abstr. Assoc. Res. Otolaryngol. 17 (1994) 137. 